\title{
Hypoglycemic Effect of Insulin-like Growth Factor II (IGF- II) Is Mediated Mainly through Insulin and/or IGF-I Receptor but not IGF-II Receptor
}

Naomi Hizuka, Kumiko Asakawa-Yasumoto, Kazue Takano, Izumi Fukuda,Yumiko Okubo, Tomoko Kazama, Hiroshi Demura, Kazuo Shizume, Yasumasa Marumoto and Katsu-ichi Sakano Department of Medicine, Institute of Clinical Endocrinology, Tokyo Women's Medical College, (NH, KAY, KT, IF, YO, TK, HD), Research Institute, The Foundation for Growth Science, (KShi), Molecular Biology Research Laboratory, Daiichi Pharmaceutical Co., Ltd., (YM, KSak), Tokyo, Japan

Abstract Insulin-like growth factor-II (IGF-II) has an insulin-like effect in vitro and in vivo. Recently, mutants of IGF-II have been synthesized by the site-directed mutagenesis technique, and the structure determinants for the function of IGF-II have been studied. With the availability of the biosynthetic IGF-II and IGF-II mutants, we have investigated the hypoglycemic effect of IGFII in normal rats and insulin resistant mice.

When the IGF-II mutants with markedly decreased affinities for both insulin and IGF-I receptors were injected in normal rats, the blood glucose levels slightly decreased. However, when IGF-II mutant with slightly decreased affinities for both insulin and IGF-I receptors was injected, the blood glucose decreased to the same extent as with IGF-II.

In insulin resistant mice, insulin did not decrease the blood glucose levels, but, the blood glucose levels decreased after IGF-I and IGF-II injection. The hypoglycemic effect of IGF-II was greater than that of IGF-I. The IGF-II mutant without affinity for IGF-II receptor but with affinities for both IGF-I and insulin receptors the same as IGF-II, caused hypoglycemia the same as IGFI. However, the IGF-II mutant with markedly decreased affinities for both insulin and IGF-I receptors did not decrease blood glucose levels, and the IGF-II mutant with slightly decreased affinities for both insulin and IGF-II receptors slightly decreased blood glucose levels.

These data indicate that the hypoglycemic effect of IGF-II is mediated mainly through insulin and/or IGF-I receptor but not IGF-II receptor. Furthermore, the data suggest that IGF-II might also be useful for the treatment of the insulin resistant status.

Key words: IGF-II, hypoglycemia, IGF receptor, insulin resistant status

\section{Introduction}

Correspondence: Dr. Naomi Hizuka, Department of Medicine, Institute of Clinical Endocrinology, Tokyo Women's Medical College, 8-1 Kawadacho, Shinjuku-ku, Tokyo 162 Japan
Insulin-like growth factor-II (IGF-II) has homologous sequences of IGF-I, and IGF-II has 


\section{Hizuka et al.}

similar biological effects as IGF-I. There are two types of IGF receptors: IGF-I receptor has a high degree of homology with insulin receptor but IGF-II receptor does not. IGF-II binds to its own IGF-II receptor with high affinity, and also binds to receptors for IGF-I and insulin with varying affinities (1). Recently, the mutants of the IGF-II have been synthesized by the site-directed mutagenesis technique as well as IGF-I, and the structural determinants for the binding of IGFs to IGF receptors and IGF binding proteins (IGFBPs) have been clarified (2-7; Fig. 1). Several reports have shown that the residues at position 24,25 and 26 in B-chain and at 3 in A-chain of insulin are important in maintaining the affinity of insulin for the insulin receptor. Similarly as with insulin, it has been shown that the residues at position 23 and 24 in IGF-I and those at 26, 27 and 43 in IGF-II are involved in insulin and IGF-I receptor binding. In addition, the residue at position 31 in IGF-I, and those at 7 and 8 in IGF-II are involved in IGF-I and insulin receptor binding. Furthermore, for IGF-II receptor binding, the residues at position 49 - 51 in IGF-I and those at $48-50$ in IGF-II are involved, and the residues at 8,54 and 55 in IGF-II are also involved. With the availability of the biosynthetic IGF-II mutants with altered affinities for insulin and IGFs receptors, the biological effects of IGF-II have been investigated to observe that IGF-II acts through which receptors for IGF-II, IGF-I and/or insulin. It was reported that the effects of IGF-II on deoxyribonucleic acid (DNA) synthesis and glycogen synthesis occurred through IGF-I receptor, but not IGF-II receptor $(3,4)$. In the present study, we have investigated to determine whether
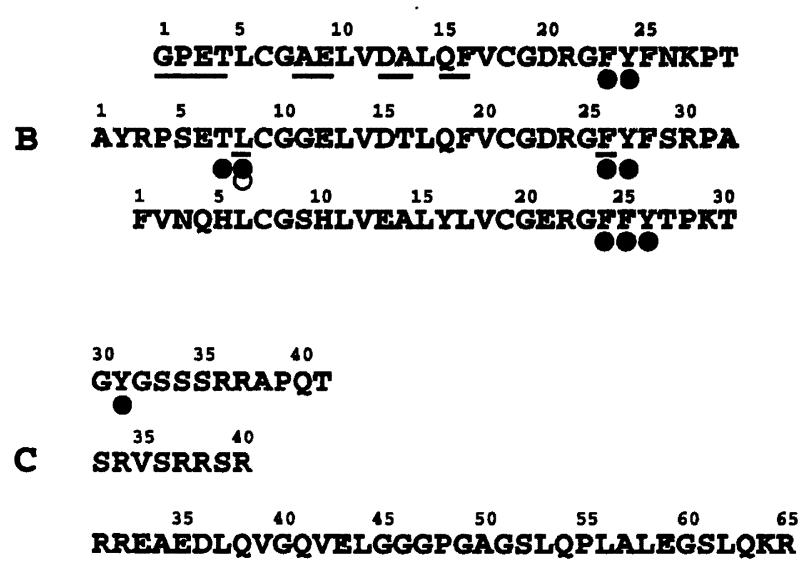

A
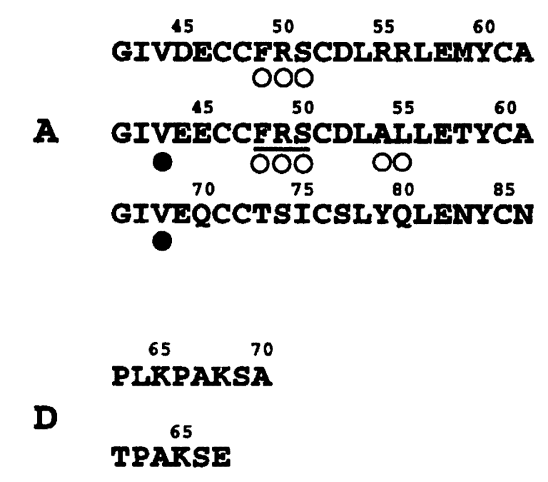

Fig. 1 Amino acid sequences of human IGF-I (upper), IGF-II (middle) and proinsulin (lower), and the residues involved in IGF-I/insulin receptor binding (๑), IGF-II receptor binding $(\bigcirc)$ and IGFBPs (underline). Data were summarized from reports (2-7).

the hypoglycemic effect of IGF-II is mediated through IGF-II receptor or not in normal rats.

IGF-I treatment has been carried out in patients with insulin resistant diabetes $(8,9)$. As IGF-II has the same hypoglycemic effect as same as IGF-I (10), IGF-II also might be a candidate for treatment of insulin resistant diabetes. Therefore, we also have studied the hypoglycemic effect of IGF-II in insulin resistant mice. 


\section{Hypoglycemic Effect of IGF-II}

\section{Materials and Methods}

\section{Peptides}

Human IGF-I (kindly provided by Fujisawa Pharmaceutical Co., Osaka, Japan) and IGF-II were prepared by recombinant DNA technique. Four recombinant human IGF-II mutants, [Ser ${ }^{26}$ ] IGF-II, [ $\mathrm{Leu}^{27}$ ] IGF-II, [Leu ${ }^{43}$ ] IGF-II, and [ $\left.\mathrm{Arg}^{54}, \mathrm{Arg}^{55}\right]$ IGF-II, shown in Fig. 2 , were prepared by site-directed mutagenesis of IGF-II, inserted into baculovirus vectors and expressed as fusion proteins in Bombyx mori silkworm larvae, as reported previously (3).

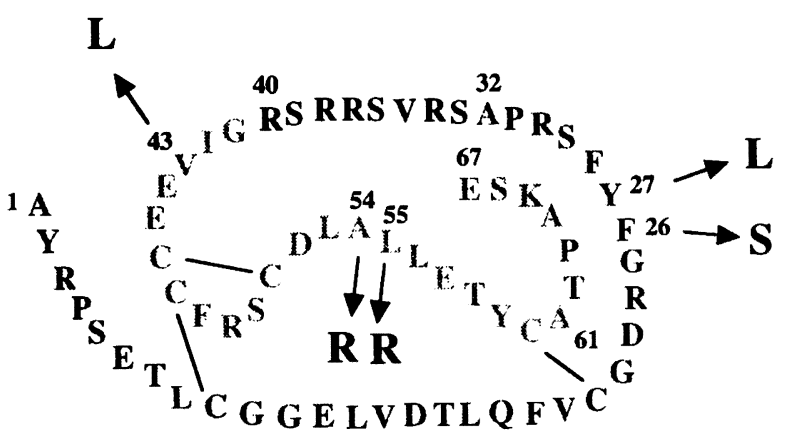

Fig. 2 Structure of hIGF-II and amino acid substitutions introduced into the four IGF-II mutants, $\left[\mathrm{Ser}^{26}\right],\left[\mathrm{Leu}^{27}\right],\left[\mathrm{Leu}^{43}\right]$, and $\left[\mathrm{Arg}^{54}, \mathrm{Arg}^{55}\right]$ IGF-IIs.

Table 1 Relative affinity of IGF-II analogs for IGFI, IGF-II and insulin receptors

\begin{tabular}{|c|c|c|c|}
\hline \multirow[t]{2}{*}{ Ligand } & IGF-II R & IGF-I R & Insulin R \\
\hline & \multicolumn{3}{|c|}{ (\% of IGF-II) } \\
\hline IGF-II & 100 & 100 & 100 \\
\hline [Ser $\left.{ }^{26}\right]$ IGF-II & 30 & 20 & 4 \\
\hline$\left[\mathrm{Leu}^{27}\right] \mathrm{IGF}-\mathrm{II}$ & 60 & 0.8 & 1.1 \\
\hline$\left[\right.$ Leu $\left.^{43}\right]$ IGF-II & 50 & 1.3 & 0.5 \\
\hline$\left[\mathrm{Arg}^{54}, \mathrm{Arg}^{55}\right]$ IGF-II & no inhib. & 125 & 200 \\
\hline
\end{tabular}

Data were summarized from reports $(3,6,7)$.
The relative affinities of IGF-II and IGF-II mutants for IGF and insulin receptors are summarized in Table 1. [Ser ${ }^{26}$ ] IGF-II, [Leu $\left.{ }^{27}\right]$ IGF-II, and [Leu ${ }^{43}$ IGF-II have decreased affinities for both insulin and IGF-I receptors but not so significantly decreased affinities for IGF-II receptor. [Leu ${ }^{27}$ ] IGF-II and [Leu ${ }^{43}$ ] IGF-II have markedly decreased affinities for both insulin and IGF-I receptors. In comparison with these mutants, [Ser $\left.{ }^{26}\right]$ IGF-II has slightly decreased affinities for those receptors. [Arg $\left.{ }^{54}, \mathrm{Arg}^{55}\right]$ IGF-II does not have affinitity for IGF-II receptor, but does not have decreased affinities for both insulin and IGF-I receptors.

\section{Effect of IGF-II in Normal Rats}

IGF-I, IGF-II, and the three IGF-II mutants, [Ser ${ }^{26}$ ] IGF-II, [Leu $\left.{ }^{27}\right]$ IGF-II, [Leu ${ }^{43}$ ] IGF-II, were injected to normal SD male rats (87-98 $\mathrm{g}$ ) as iv bolus at a dose of $1 \mathrm{mg} / \mathrm{kg}$, and blood glucose levels were measured. As control, saline was injected.

\section{Effect of IGF-II in Insulin Resistant Mice}

Insulin resistant obese mice were prepared by treating with goldthioglucose (GTG) (11). GTG was ip injected at a dose of 500 $\mathrm{mg} / \mathrm{kg}$ to normal male ICR mice aged six weeks, and then the mice had free access to drinking water and food for eight weeks. IGFII $(1 \mathrm{mg} / \mathrm{kg})$, IGF-I $(1 \mathrm{mg} / \mathrm{kg})$, insulin $(1 \mathrm{U} / \mathrm{kg})$ were ip injected to the insulin resistant (GTG treated) mice. As control, $0.1 \mathrm{~N}$ acetic acid was injected. The dosages of the peptides were determined using normal male mice. 


\section{Hizuka et al.}

\section{Results}

\section{Effect of IGF-II and IGF-II Mutants in Normal Rats}

When normal rats received $1 \mathrm{mg} / \mathrm{kg}$ IGF-II as iv bolus injection, the blood glucose levels (\% of basal level) decreased to $47.2 \pm 5.2 \%$ (Mean $\pm \mathrm{SEM}$ ) at $30 \mathrm{~min}$, and $52.7 \pm 4.2 \%$ at $60 \mathrm{~min}$ after injection. IGF-I at a dose of 1 $\mathrm{mg} / \mathrm{kg}$ caused hypoglycemia, and the blood glucose levels were $43.4 \pm 2.7 \%$ at $30 \mathrm{~min}$ and $46.4 \pm 4.8 \%$ at $60 \mathrm{~min}$ after injection. The blood glucose levels after IGF-II injection did not differ from those after IGF-I injection.

We tested three mutants of IGF-II with altered affinity for receptors of IGF-I and insulin. When [ $\left.\mathrm{Leu}^{27}\right]$ IGF-II or [ $\left.\mathrm{Leu}^{43}\right]$ IGF-II was injected, the blood glucose levels decreased slightly from $68 \pm 6$ or $64 \pm 3$ to 58 \pm 1 or $55 \pm 4 \mathrm{mg} / \mathrm{dL}$, respectively (Fig. 3 ). How-

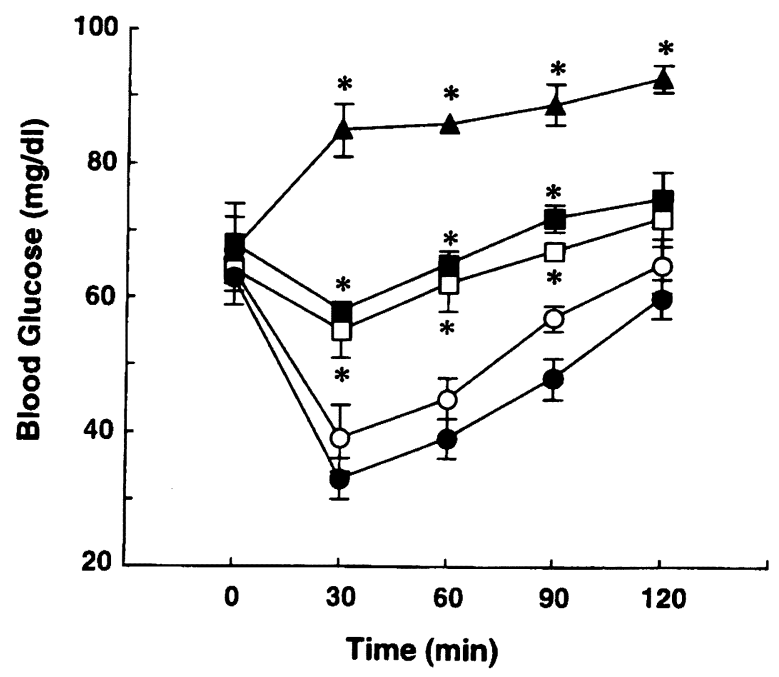

Fig. 3 Blood glucose levels after iv bolus injection of IGF-II and IGF-II mutants $(1 \mathrm{mg} / \mathrm{kg})$ in normal rats. IGF-II (O), [Ser $\left.{ }^{26}\right]$ IGF-II (๑), [Leu $\left.{ }^{27}\right]$ IGF-II $(\boldsymbol{\square})$, [Leu $\left.{ }^{43}\right]$ IGF-II ( $\square$ ), and saline $(\boldsymbol{\Delta})$. The data are expressed as the Mean \pm SEM.

$* \mathrm{P}<0.05$ (vs IGF-II). ever, the blood glucose levels were significantly lower than those for saline injection. When [Ser ${ }^{26}$ ] IGF-II was injected, the blood glucose decreased to the same extent as IGFII (Fig. 3).

\section{Effect of IGF-II and IGF-II Mutants in GTG Treated Mice}

In normal mice, $1 \mathrm{U} / \mathrm{kg}$ insulin injection caused hypoglycemia and was equipotent to 1 $\mathrm{mg} / \mathrm{kg}$ IGF-I and IGF-II (Fig. 4). Therefore, we tested the peptides at these dosages for the GTG treated mice. In the GTG treated mice, insulin ( $1 \mathrm{U} / \mathrm{kg}$ ) did not decrease the blood glucose levels but the blood glucose levels decreased after $1 \mathrm{mg} / \mathrm{kg}$ IGF-I or IGF-II injection (Fig. 4). The blood glucose levels after IGF-II injection were $59.8 \pm 5.0 \%$ of basal level at $60 \mathrm{~min}$ and $57.5 \pm 5.9 \%$ at $90 \mathrm{~min}$, and the values were significantly lower than those after IGF-I injection (78.0 \pm 6.5 and $78.6 \pm 5.8$ $\% ; \mathrm{P}<0.05$; respectively).
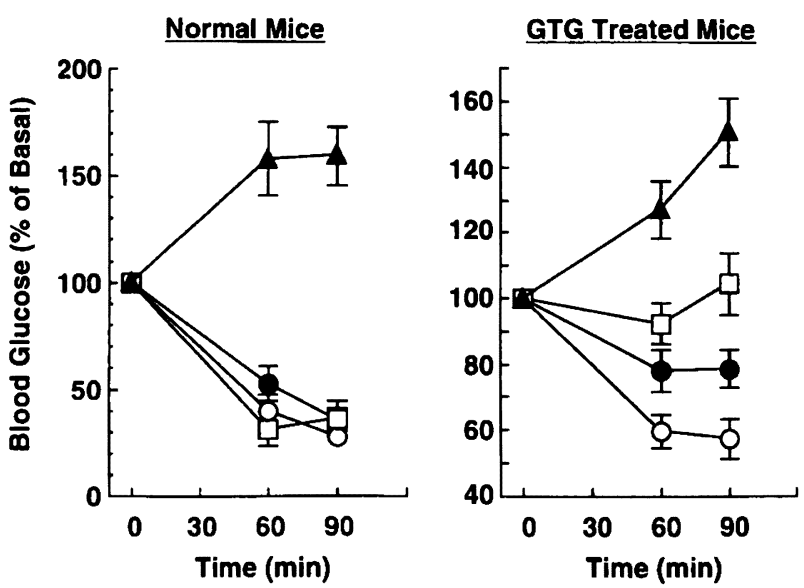

Fig. 4 Blood glucose levels after ip injection of insulin $(1 \mathrm{U} / \mathrm{kg})(\square)$, IGF-I (1 mg/kg)(@), or IGF-II (1 $\mathrm{mg} / \mathrm{kg})(\bigcirc)$ in normal mice (left) and insulin resistant (GTG treated) mice (right). $0.1 \mathrm{~N}$ acetic acid was injected as control $(\boldsymbol{\Delta})$. The data are expressed as the Mean \pm SEM. 


\section{Hypoglycemic Effect of IGF-II}

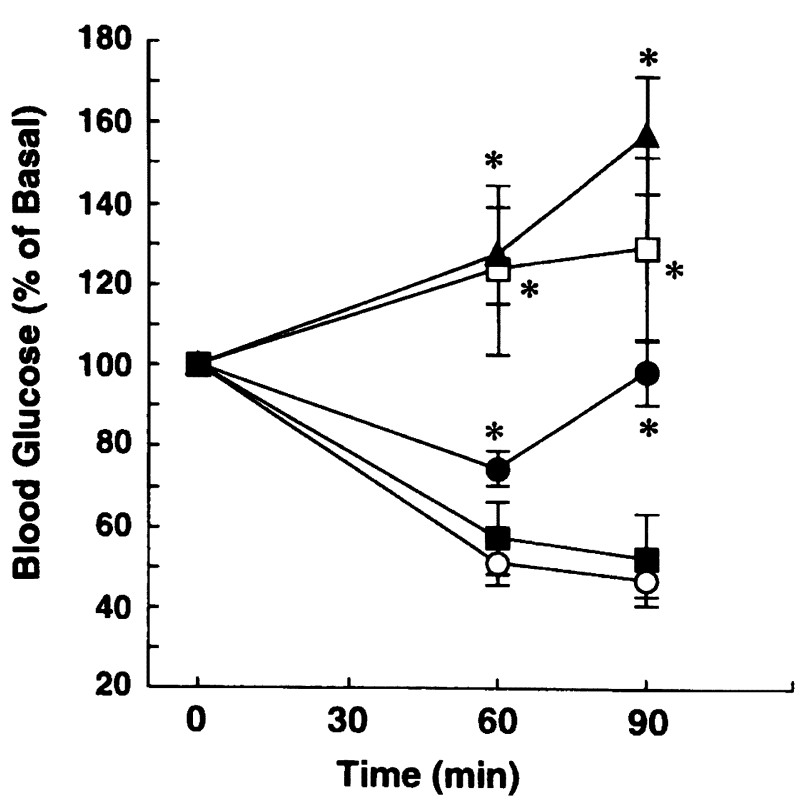

Fig. 5 Blood glucose levels after ip injection of IGF-II and IGF-II mutants ( $1 \mathrm{mg} / \mathrm{kg})$ in insulin resistant (GTG treated) mice. IGF-I( $\bigcirc)$, [Ser $\left.{ }^{26}\right]$ IGF-II(๑), [Leu $\left.{ }^{43}\right]$ IGF-II( $\left.\square\right)$, $\left[\mathrm{Arg}^{54}, \mathrm{Arg}^{55}\right]$ IGF-II(口) and control( $\Delta)$. The data are expressed as the Mean \pm SEM.

${ }^{*} \mathrm{P}<0.05$ (vs IGF-II).

We tested three mutants of IGF-II with altered affinities for IGF and insulin receptors in the insulin resistant mice (Fig. 5). [Arg54, $\mathrm{Arg}^{55}$ ] IGF-II caused hypoglycemia the same as IGF-II. However, [Leu ${ }^{43}$ ] IGF-II did not decrease blood glucose levels and [Ser $\left.{ }^{26}\right]$ IGFII slightly decreased blood glucose levels.

\section{Discussion}

IGF-II has a hypoglycemic effect in vivo, however, it is not known that the hypoglycemic effect of IGF-II is mediated through which receptors for IGF-II, IGF-I and/or insulin. In the present study, we investigated the hypoglycemic effect of IGF-II in normal rats using IGF-II mutants with altered affinities for insulin and IGF receptors, synthesized by sitedirected mutagenesis. The mutants of IGF-II with markedly decreased affinities for both insulin and IGF-I receptors, [Leu ${ }^{27}$ ] IGF-II or [Leu $\left.{ }^{43}\right]$ IGF-II, slightly decreased blood glucose levels. However, the mutant with slightly decreased affinities for both insulin and IGF-I receptors, [Ser $\left.{ }^{26}\right]$ IGF-II, decreased blood glucose levels to the same extent as IGF-II. These data indicate that the hypoglycemic effect of IGF-II is mediated through mainly insulin and/or IGF-I receptors, but not IGF-II receptor.

As IGF-II has a hypoglycemic effect, IGFII could be one of the candidates for the treatment of insulin resistant diabetes as well as IGF-I. In insulin resistant mice, both IGF-I and IGF-II had a hypoglycemic effect, but the effect of IGF-II was greater than that of IGF-I. We investigated the hypoglycemic effect of three IGF-II mutants in insulin resistant mice. The IGF-II mutant, [Arg54, Arg55] IGF-II, without affinity for IGF-II receptor but with affinities for both IGF-I and insulin receptors the same as IGF-II, caused hypoglycemia the same as IGF-II. However, [Leu ${ }^{43}$ ] IGF-II, with markedly decreased affinities for both insulin and IGF-I receptors did not decrease blood glucose levels, and [Ser ${ }^{26}$ ] IGF-II with slightly decreased affinities for both insulin and IGF-II receptors slightly decreased blood glucose levels. These data suggested that the hypoglycemic effect of IGF-II in the insulin resistant mice might not be mediated through the IGF-II receptor. It is not clear why the hypoglycemic effect of IGF-II in insulin resistant mice was greater than that of IGF-I, in spite of the fact that the effect of IGF-II is mediated through receptors for IGF-I and/or insulin but not IGF-II receptor. This may be 


\section{Hizuka et al.}

because the IGF-II mutants have altered affinity with IGFBPs as well as receptors for IGFs and insulin (5-7), or because IGF-II has greater affinity for insulin receptor than IGFI (3). However, the reason remains to be clarified. Our present data suggest that IGFII might be useful for treatment of the insulin resistant status.

\section{Acknowledgements}

This work was supported in part by Grants-in-Aid for General Scientific Research (No.06671058 and 06671059) and a Grant-inAid for Encouragement of Young Scientists (No.07770842) from the Ministry of Education, Science and Culture, a research grant from the Intractable Disease Division, Public Health Bureau, the Ministry of Health and Welfare, and The Takako Satake Scholarship Fund.

\section{References}

1. Jones JI, Clemmons DR. Insulin-like growth factors and their binding proteins; Biological actions. Endocrine Reviews 1995; 16: 3-34.

2. Cascieri MA, Bayne ML. Analysis of the interaction of IGF-I analogs with the IGFI receptor and IGF binding proteins. In: LeRoith D, Raizada MK, editors. Current Directions in Insulin-Like Growth Factor Research, Plenum Press, New York, 1994: 3340 .

3. Sakano K, Enjoh T, Numata F, Fujiwara $\mathrm{H}$, Marumoto $\mathrm{Y}$, Higashihashi $\mathrm{N}$, et al. The design, expression, and characterization of human insulin-like growth factorII (IGF-II) mutants specific for either the
IGF-II/cation-independent mannose 6phosphate receptor or IGF-I receptor. J Biol Chem 1991; 266: 20626-35.

4. Beukers MW, Oh Y, Zhang H, Ling, Rosenfeld RG. (Leu ${ }^{27}$ ) insulin-like growth factor II is highly selective for the type-II IGF receptor in binding, cross-linking and thymidine incorporation experiment. Endocrinology 1991; 128: 1201-3.

5. Oh Y, Muller HL, Zhang H, Ling N, Rosenfeld RG. Synthesis and characterization of IGF-II analogs: Applications in the evaluation of IGF receptor function and IGF-independent actions of IGFBPs. In: LeRoith D, Raizada MK, editors. Current Directions in Insulin-Like Growth Factor Research, Plenum Press, New York, 1994: 4154.

6. Bach LA, Hsieh S, Sakano K, Fujiwara H, Perdue JF, Rechler MM. Binding of mutants of human insulin-like growth factor II to insulin-like growth factor binding proteins 1-6. J Biol Chem 1993; 268: 9246-54.

7. Perdue JF, Bach LA, Hashimoto R, Sakano K, Fujita-Yamaguchi Y, Fujiwara $\mathrm{H}$, et al. Structural determinants for the binding of insulin-like growth factor-II to IGF and insulin receptors and IGF binding proteins. In: Baxter RC, Gluckman PD, Rosenfeld RG, editors. The Insulin-Like Growth Factors and Their Regulatory Proteins. Elsevier Science BV, Amsterdam, 1994: 67-76.

8. Schoenle EJ, Zenobi PD, Torresani T, Werder EA, Zachmann M, Froesch ER. Recombinant human insulin-like growth factor I (rhIGF-I) reduces hyperglycemia in patients with extreme insulin resis- 
tance. Diabetologia 1991; 34: 675-9.

9. Kuzuya $H$, Matsuura $N$, Sakamoto $M$, Makino H, Sakamoto Y, Kadowaki T, et al. Trial of insulin-like growth factor I therapy for patients with extreme insulin resistance syndrome. Diabetes 1993; 42: 696-705.

10. Zapf J, Hauri C, Waldvogel M, Froesch ER. Acute metabolic effects and half-lives of intravenously administered insulinlike growth factor I and II in normal and hypophysectomized rats. J Clin Invest 1986; 77: 1768-75.

11. Matsuo T, Shino A. Induction of diabetic alteration by goldthioglucose-obesity in KK, ICR and C57BL mice. Diabetologia 1972, 8: 391-7. 